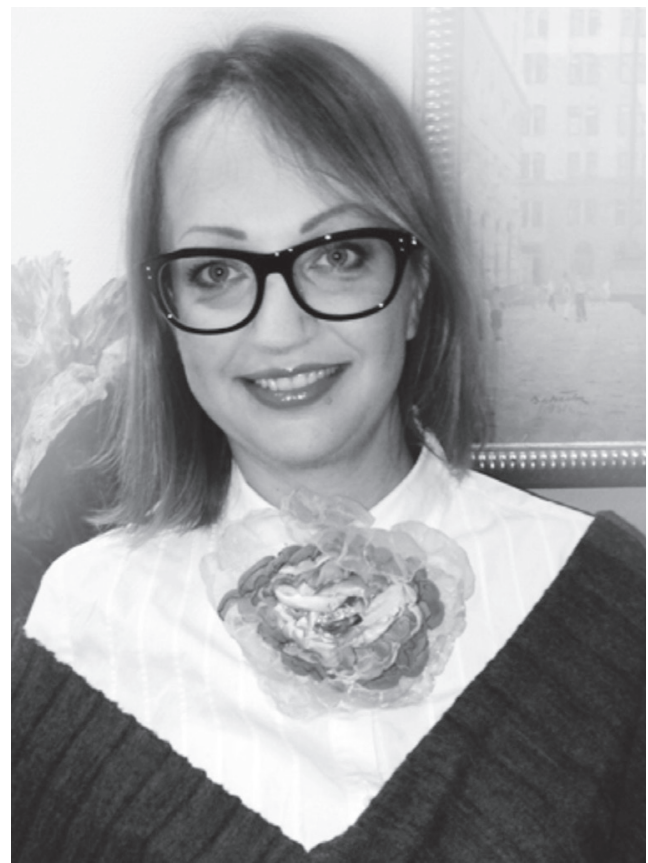

UDC: $351.329: 336.58$

DOI: https://doi.org/10.32689/2617-

2224-2019-17-2-108-121

Kustova Svitlana Mykolayizna,

PhD student of the Department of Parliamentarism and Political Management of the National Academy of Public Administration under the President of Ukraine, Honored Lawyer of Ukraine, 02000, Ukraine, Kyiz, Str. Ezhena Potier, 20, tel.: +38 (066) 03071 58, e-mail:pravoved1996@ukr.net

ORCID: 0000-0002-5387-222X

\title{
Кустова Світлана Миколаївна,
}

аспірант кафедри парламентаризму та політичного менеджменту, Національна академія державного управління при Президентові України, Заслужений юрист України. 02000, Україна, Київ, вул. Ежена Потье, 20, тел.:+38 (066) 03071 58, e-mail:pravoved1996@ukr.net

ORCID: 0000-0002-5387-222X

\section{Кустова Светлана Николаевна,}

аспирант кафедры парламентаризма и политического менеджмента, Национальная академия государственного управления при Президенте Украины. Заслуженный юрист Украины. 02000, Украина, Киев, ул. Эжена Потье, 20, тел.:+38 (066) 03071 58, e-mail:pravoved1996@ukr.net

ORCID: 0000-0002-5387-222X

\section{MAIN PRINCIPLES FOR REGULATION OF PUBLIC FINANCING OF POLITICAL PARTIES: EXPERIENCE OF DEVELOPED DEMOCRACY COUNTRIES AND UKRAINE}

Abstract. The article considers the generalized experience of developed democracies in relation to the legal foundations of state regulation of financing of political parties and the practical possibilities of using it in Ukraine. The article analyzes the provisions of the draft laws on changes in the system of state regulation of financing of political parties in Ukraine and suggests ways to improve it.

It has been shown that the experience of state funding of political parties in developed democracies, in particular, in European countries, is successful. It is noted that the efficiency and effectiveness of the system of financing political parties does not depend on the existence of a special law on financing. It is noted that such social relations can be regulated as separate legislative acts, as well as in the 
form of a system of provisions in various laws - constitutions, party laws, electoral legislation, anti-corruption laws.

It is argued that state financing of political parties is one of the effective tools in the fight against political corruption and provision of parties with the necessary resources for statutory activities and their development.

The author draws attention to the European practice of state financing of the activities of political parties, which have a high rating, and those that only nominate candidates for elections. This can guarantee equality of opportunity for various political forces. So, public funding must be determined in proportion to the political support that the party has received. At the same time, the author is convinced that excessive dependence on state financing may lead to a weakening of ties between parties and their electorate.

The article also states that in the European experience state and private funding of political parties is allocated. Public financing takes place both by statutory activities and by campaign expenditures. It is direct (subsidizing) and indirect (benefits on a legislative basis). It is established that the state support of political parties in European countries ranges from more than $20 \%$ to $85 \%$ of the total budget of parties.

The author is convinced that the experience of developed democracies should be taken into account in Ukraine with the aim of solving existing problems and preventing them in the future, which will strengthen party competition, internal party democracy, and ensure the proper realization of the function of political parties as a connecting link between civil society and the state.

Keywords: financing of political parties, state regulation, state administration, financial reporting, concept of state financing of parties.

\section{ОСНОВНІ ПРИНЦИПИ РЕГУЛЮВАННЯ ДЕРЖАВНОГО ФІНАНСУВАННЯ ПОЛІТИЧНИХ ПАРТІЙ: ДОСВІД КРАЇН РОЗВИНЕНОЇ ДЕМОКРАТІЇ ТА УКРАЇ̈А}

Анотація. Розглянуто узагальнений досвід країн розвиненої демократії щодо правових засад державного регулювання фінансування політичних партій та практичні можливості використання його в Україні. Проаналізовано положення законопроектів щодо змін у системі державного регулювання фінансування політичних партій в Україні та запропоновано шляхи її вдосконалення.

Показано, що досвід державного фінансування політичних партій в країнах розвиненої демократії, зокрема в країнах Європи, є успішним. Зазначено, що ефективність та дієвість системи фінансування політичних партій не залежить від наявності в ній спеціального закону щодо фінансування. Наголошується, що такі суспільні відносини можуть бути врегульовані як окремими законодавчими актами, так і у вигляді системи положень в різних законах - конституціях, законах про партії, виборчому законодавстві, законах про боротьбу з корупцією. 
Аргументується, що державне фінансування політичних партій є одним із дієвих інструментів у боротьбі з політичною корупцією та забезпеченні партій необхідними ресурсами для статутної діяльності та розвитку. Наведено приклади європейського досвіду державного фінансування діяльності політичних партій, які мають великий рейтинг, і тих, що тільки висувають кандидатів на виборах. Це може гарантувати рівність можливостей для різних політичних сил. Отже, державне фінансування має визначатися пропорційно до політичної підтримки, яку партія отримала. Разом з тим, надмірна залежність від державного фінансування може призвести до послаблення зв'язків між партіями та їхнім електоратом.

У європейському досвіді виокремлюють державне та приватне фінансування політичних партій. Державне відбувається як фінансування статутної діяльності, та як фінансування витрат на виборчі кампанії. Воно буває пряме (субсидіювання) та непряме (вигоди на законодавчій підставі). Встановлено, що державна підтримка політичних партій у країнах Європи коливається від більш ніж 20 \% до 85 \% від загального бюджету партій.

Досвід країн розвиненої демократії має бути врахований в Україні з метою вирішення вже існуючих проблем та уникнення їх у майбутньому, що посилить партійну конкуренцію, внутрішньопартійну демократію, забезпечить належну реалізацію функції політичних партій як сполучної ланки між громадянським суспільством та державою.

Ключові слова: фінансування політичних партій, державне регулювання, державне управління, фінансова звітність, поняття державного фінансування партій.

\section{ОСНОВНЫЕ ПРИНЦИПЫ РЕГУЛИРОВАНИЯ ГОСУДАРСТВЕННОГО ФИНАНСИРОВАНИЯ ПОЛИТИЧЕСКИХ ПАРТИЙ: ОПЫТ СТРАН РАЗВИТОЙ ДЕМОКРАТИИ И УКРАИНА}

Аннотация. Рассмотрен обобщенный опыт стран развитой демократии относительно правовых основ государственного регулирования финансирования политических партий и практические возможности использования его в Украине. Проанализированы положения законопроектов об изменениях в системе государственного регулирования финансирования политических партий в Украине и предложены пути ее совершенствования.

Показано, что опыт государственного финансирования политических партий в странах развитой демократии, в частности в странах Европы, является успешным. Отмечено, что эффективность и действенность системы финансирования политических партий не зависит от наличия в ней специального закона о финансировании. Отмечается, что такие общественные отношения могут быть урегулированы как отдельными законодательными актами, так и в виде системы положений в различных законах - конституциях, законах о партиях, избирательном законодательстве, законах о борьбе с коррупцией.

Аргументируется, что государственное финансирование политических партий является одним из действенных инструментов в борьбе с политиче- 
ской коррупцией и обеспечении партий необходимыми ресурсами для уставной деятельности, их развития.

Приводится пример европейской практики государственного финансирования деятельности политических партий, которые имеют большой рейтинг, и тех, что только выдвигают кандидатов на выборах. Это может гарантировать равенство возможностей для различных политических сил. Итак, государственное финансирование должно определяться пропорционально политической поддержкой, которую партия получила. Вместе с тем, чрезмерная зависимость от государственного финансирования может привести к ослаблению связей между партиями и их электоратом.

В европейском опыте выделяют государственное и частное финансирование политических партий. Государственное финансирование происходит как финансирование уставной деятельности, и как расходов на избирательные кампании. Оно бывает прямое (субсидирование) и косвенное (льготы на законодательной основе). Установлено, что государственная поддержка политических партий в странах Европы колеблется от более чем 20 \% до 85 \% от общего бюджета партий.

Опыт стран развитой демократии должен быть учтен в Украине с целью решения существующих проблем и предотвращения их в будущем, что усилит партийную конкуренцию, внутрипартийную демократию, обеспечит надлежащую реализацию функции политических партий в качестве связующего звена между гражданским обществом и государстBOM.

Ключевые слова: финансирование политических партий, государственное регулирование, государственное управление, финансовая отчетность, понятие государственного финансирования партий.

Problem statement. For Ukraine, the study of the legal regulation of the financing of political parties is particularly relevant in the context of the still rather small experience of the rule in the Law of Ukraine "On political parties in Ukraine" [1], which entered into force on July 1, 2016 [2], which introduced state funding of political parties. Adaptation of foreign experience of state regulation of financing of political parties in Ukraine is of particular importance for the development of democracy and improving the efficiency of the government.
Analysis of recent publications on the subject and identification of previously unsolved parts of the overall problem. In the second half of the $20^{\text {th }}$ century the issues of state funding of statutory activities of political parties were viewed mainly in the context of socio-political demarcation, structuring of society and its democratization (works of S. Bartolini [3], P. Meir [4], I. Baj [5], H. Keman [6], M. Lever [7], N. Shofild [8], V. Hunt [9] A. Niedermeijer [10], K. Jandhi [9], R. Hermel [9], K. Edens [9], P. Goff [10], R. Delton [11-13], S. Flanagan [15], A. Vera [16], 
L. Helms [17]). In Ukraine recently the issue of the funding of political parties has become the object of research of such scientists - L. Goniukova [18] O. Kotsiurba [19], S. Obushnyi [20], M. Prymush [21], R. Martyniuk [22], A. Romaniuk [23], Yu. Shweda [24] and O. Shumeld [25], both in the context of broader issues and problems of structuring societies, and in connection with questions of government accountability, efficiency and fair functioning of the mechanism of state regulation.

Formulation of the article objectives (problem statement). The purpose of the article is to study and highlight some features of foreign experience of state regulation of financing of political parties in the historical context and the possibilities of its adaptation in Ukraine. Based on this goal, the main objectives of the article are to analyze the principles and forms of state financing of political parties in the countries of developed democracy in the historical context and to propose ways to improve the mechanisms of state regulation regarding the financing of political parties in Ukraine.

Presentation of the main results. State funding contributes to the ideologization of the newly created parties, in addition, parties can easily get used to it and can no longer do without it. But, in our opinion, the main advantages of budget support for political parties is to stimulate the development of political competition, increasing the intensity and quality of political struggle (by taking part in it ин less wealthy, but more ideological parties), makes those parties that already have a high level of support from citizens financially independent.
According to the definition used by V. V. Dzhugan, "financing of political parties is the activity of political parties, public authorities, individuals and legal entities carried out in the manner and within the limits established by the current legislation, which is aimed at providing political parties with financial and other resources that are amenable to financial assessment and that are necessary for political parties to realize their goals and objectives" [26].

The principles on which funding should be based have been the subject of scientific research since the beginning of this century. Thus, the basic principles of regulation of state financing of political parties are presented in L. Young's monograph "Regulation of political financing in liberal democratic societies" [27]. The author investigates the strengths and weaknesses of different approaches to the regulation of financial support of election campaigns and explores the theoretical issues that are the foundations of such funding. In scientific work edited by R. Williams "Party financing and political corruption" [28] an in-depth study of party financing and problems of political corruption was carried out. The author observes that "the sources, extent, shape, distribution of party funding have profound political consequences" [29, p. 5]. Therefore, this process should be regulated and based on clear principles.

The basic principles of state financing of political parties in the countries of developed democracy, in particular, in Europe, is now the object of study and domestic experts. Expert of the National Institute for strategic studies under the President of Ukraine S. Yanishevskyi [30] for this purpose analyzed 
the documents of the Venice Commission, PACE, Committee of Ministers of the Council of Europe [31; 32-34]. V. Dzhugan carried out a comparative analysis of the constitutional and legal basis for the financing of political parties in Ukraine and the EU [35]. In general, the consequences of state funding of political parties have been studied since the middle of the last century. The researchers' conclusions on this matter are ambiguous. For example, K. Strom [36] put forward a theory according to which state funding increases the independence of party leaders from activists, while J. Schlesinger [37] believes that it contributes to the bureaucratization of parties. But the study of the mechanism of state subsidies to parties in Austria, Italy, Sweden and Germany conducted by K.-H. Nassmacher [38] shows that both conclusions have the right to exist.

The analysis of these sources allows us to establish that the state regulation of the financing of political parties is based on such principles as equality, diversity of funding sources, proportionality, reasonableness and validity of the balance between public and private financing, fairness of the distribution of state fixation between the parties, restrictions of private financing by nature and size, transparency of financing, and accountability. They mean that public funding should be allocated to each party represented in the parliament.

Public funding can be extended to political bodies that represent an important part of the electorate, as well as to those that nominate candidates in elections, which guarantees equal opportunities for different political forces. Public funding should be determined in proportion to the political support that the party has received. It should also be based on objectivity, namely, funding based on calculations based on objective criteria such as the number of votes cast or seats obtained in Parliament and the ability of new parties to appear in the political arena, competing on fair terms with parties that have longstanding strong positions. Excessive reliance on public funding can weaken the links between parties and their electorate. A political party at the European level must annually publish its income, expenses and declaration on its assets and liabilities, declare its sources of funding by providing a list that indicates the donors and received from each donor that exceeds 500 euros. Regarding the forms of financing, public and private funding are allocated. The state takes place as the financing of the statutory activities, and the financing of the costs of election campaigns of political parties. Budget funding is divided into direct financing (subsidies) and indirect (convenience on a legislative basis), in particular, by covering postage and rental of premises for meetings, support of party media, youth organizations and research institutions, as well as by providing tax incentives, etc [39]. State funding is received by both parliamentary parties and parties that are not in the parliament. In general, state support for political parties in Europe ranges from more than $20 \%$ to $85 \%$ of the total budget of the parties [40].

In Ukrainian society, discussions about the financing of political parties from the state budget and the direction of expenditure of these funds by political parties often have negative content and little support. In 2015, only $15 \%$ 
of citizens supported the financing of parties from the budget, respectively $15,7 \%$ - in 2016 and 9,9 \% - in 2017 considered funding from the state budget acceptable. Thus, few citizens support state funding of political parties, because so few citizens trust thembefore and after 2013, these institutions were trusted no more than by the fifth of the respondents [41].

As for the main drawbacks, in our opinion, this was noticed in the second half of the last century - there are certain problems regarding the sources of financing of parties, especially with respect to public financing, which are associated with political competition, transparency and accountability of parties, dependence of political and state power, corruption. Tsatsos D., Botha M., Blackman A. in the work "Financing of political parties: a comparative legal study" [42], having analyzed the legislation of Germany, Sweden, France, Great Britain, Italy and other countries, identified the need to develop state instruments for regulating the financing of political parties and showed the need to improve the legislation, noting that the imperfect mechanism of control over the financing of political parties, including public financing, is the cause of problems of public administration. In addition, P. Kopetski found that among the disadvantages of budget funding is that a lot of parties in southern European countries almost completely dependent on the state, and in other countries, public funding is "symbolic" in comparison with private and corporate donations [43, p. 262].

In Ukraine, public relations in the sphere of public administration and administration regarding state funding of political parties are regulated by the Constitution of Ukraine [44], the laws of Ukraine "On political parties in Ukraine" [45], "On elections of people's deputies of Ukraine" [46]. The forms and amount of state funding of political parties, the procedure for allocation and distribution of funds between political parties to finance their statutory activities, the grounds for termination of state funding, and the like are determined. But since then, there is a number of separate issues on the practical implementation of the provisions of the Law of Ukraine "On political parties in Ukraine" in terms of the order of distribution of funds between political parties to finance their statutory activities, the amount of funding of political parties, the period of use of funds by political parties to Finance their statutory activities. In connection with 2016 (the time of the introduction of the rule on finance) in the legislature from time to time legislators register draft laws on improving the state regulation of the financing of political parties and even the abolition.

Please note that the generalized experience of state financing of political parties in the European Union indicates the need for a clear regulation at the legislative level of the procedure of state financial support of parties. Taking into account the experience of financing political parties in the countries of the European Union in Ukraine will improve the procedure of state financing of political parties, introduce a clear mechanism for the distribution of funds between political parties to finance their statutory activities, transparency of such financing and proper financial 
control. To solve these problems bills № 5446 of 24.11.2016 and № 6026 of 03.02.2017 on amendments to the laws of Ukraine on the targeted use of state funding of the statutory activities of political parties are currently registered in the Verkhovna Rada of Ukraine.

Summary. The issue of expediency and necessity of financing of political parties at the expense of means of the state budget is actively debated not only in Ukraine, but also in many countries of the European Union where it successfully works for rather long period. The synthesis of the experience of state financing of political parties in the countries of developed democracy, in particular, in some European countries, at the highest level of European official institutions shows that, in general, with the exception of Italy, this experience is successful. The effectiveness and efficiency of the system of financing of political parties does not depend on the existence of a special law on financing, because, as the experience of European countries shows, these social relations can be regulated by separate legislative acts, and in the form of a system of provisions in different laws - constitutions, laws on parties, electoral legislation, anti-corruption laws, and the like. Public funding of political parties is an effective tool in the fight against political corruption and in providing parties with the necessary resources for statutory activities and development. The experience of developed democracy countries should be taken into account in Ukraine in order to solve existing problems and prevent them in the future, which will strengthen party competition, internal party democracy, ensure the proper implementation of the function of political parties as a binding function.

\section{REFERENCES}

1. Zakon Ukrainy "Pro politychni partii v Ukraini” : vid 01.10.2018, № 2365III [Law of Ukraine "On Political Parties in Ukraine” from 01.10.2018, № 2365-III]. (n.d.). zakon.rada.gov. ua. Retrieved from https://zakon. rada.gov.ua/laws/show/2365-14 [in Ukrainian].

2. Zakon Ukrainy "Pro vnesennia zmin do deiakykh zakonodavchykh aktiv Ukrainy shchodo zapobihannia i protydii politychnii koruptsii" : vid 08.10.2015, № 731-VIII [Law of Ukraine "On amendments to certain legislative acts of Ukraine on prevention and counteraction to political corruption" from 01.10.2018, № 2365-III]. (n.d.). zakon.rada.gov. ua. Retrieved from https://zakon.rada. gov.ua/laws/show/731-19\#n60 [in Ukrainian].

3. Bartolini St. (1990). Identity, competition, and electoral availability. The stabilization of European electorates 1885-1985. Cambridge: Cambridge University Press [in English].

4. Dalton R. J. (1985). Political parties and political representation. Party supporters and party elites in nine nations. Comparative political studies, 8(3), 267-299 [in English].

5. Budge I., Keman H. (1990). Parties and democracy. Coalition formation and government functioning in twenty states. Oxford [in English].

6. Budge I., Keman H. (1990). Parties and democracy. Coalition formation and government functioning in twenty states. Oxford [in English].

7. Laver M., Hunt W. B. (1992). Policy and party competition. New York [in English]. 
8. Laver M., Schofield N. (1990). Multiparty government. The politics of coalition in Europe. Oxford, New York [in English].

9. Laver M., Hunt W. B. (1992). Policy and party competition. New York [in English].

10. Janda K., Harmel R., Edens C., Goff P. (1995). Changes in party identity: evidence from party manifestos. Party politics, 1(2), 171-196 [in English].

11. Dalton R.J. (1985). Political parties and political representation. Party supporters and party elites in nine nations. Comparative political studies, 8(3), 267-299 [in English].

12. Dalton R. J. (1996). Citizen politics: public opinion and political parties in advanced western democracies. Chatham [in English].

13. Dalton R.J., Flanagan S. C., Beck P. A. (Eds.). (1984). Electoral change in advanced industrial democracies: realignment or dealignment? Princeton [in English].

14. Dalton R.J., Flanagan S. C., Beck P. A. (Eds.). (1984). Electoral change in advanced industrial democracies: realignment or dealignment? Princeton [in English].

15. Niedermayer O. (1996). Zur systematischen analyse der entwicklung von parteiensystemen. Wahlen und politische einstellungen in westlichen demokratien. O. W. Gabriel, J. W. Falter (Hrsg.). (s. 19-49). Frankfurt am Main: Lang [in German].

16. Ware A. (1996). Political parties and party systems. Oxford, New York [in English].

17. Helms L. (1999). Parteien und fraktionen. Ein internationaler vergleich. Opladen [in German].

18. Honiukova L. (2009). Politychni partii yak instytut derzhavnoi polityky ta upravlinnia: teoretyko-metodolohichnyi analiz [Political parties as an institute of state policy and management: theoretical and methodological analysis]. Kyiv [in Ukrainian].

19. Kotsiuruba O. (2013). Publichne finansuvannia politychnykh partii: perspektyva dlia Ukrainy na dosvidi Polshchi [Public funding of political parties: a prospect for Ukraine on the experience of Poland]. Visnyk Lvivskoho universytetu. Seriia yurydychna Visnyk of Lviv University. Series: Law, 57, 179-188 [in Ukrainian].

20. Obushnyi S. M. (2007). Finansove zabezpechennia diialnosti politychnykh partii v Ukraini [Financial support of political parties in Ukraine]. Candidate's thesis. Kyiv [in Ukrainian].

21. Prymush M. V. (2001). Polityko-pravove rehuliuvannia diialnosti politychnykh partii [Political and legal regulation of political parties activities]. Donetsk [in Ukrainian].

22. Martyniuk R. (2010). Partiina systema Ukrainy ta rehionalni chynnyky $\mathrm{v}$ yii rozvytku [The party system of Ukraine and regional factors in its development]. Politolohichni ta sotsiolohichni studii - Political science and sociology studies, 50 (9), 180-192 [in Ukrainian].

23. Romaniuk A. S., Shveda Yu. R., Shumelda O. V. (2003). Polityko-pravovi aspekty finansuvannia politychnykh partii: svitovyi dosvid ta Ukraina [Political and legal aspects of financing political parties: world experience and Ukraine]. Lviv [in Ukrainian].

24. Romaniuk A. S., Shveda Yu. R., Shumelda O. V. (2003). Polityko-pravovi aspekty finansuvannia politychnykh partii: svitovyi dosvid ta Ukraina [Political and legal aspects of financing political parties: world experience and Ukraine]. Lviv [in Ukrainian].

25. Romaniuk A. S., Shveda Yu. R., Shumelda O. V. (2003). Polityko-pravovi aspekty finansuvannia politychnykh partii: svitovyi dosvid ta Ukraina [Political and legal aspects of financing 
political parties: world experience and Ukraine]. Lviv [in Ukrainian].

26. Dzhuhan V. V. (2017). Konstytutsiinopravovi zasady finansuvannia politychnykh partii v Ukraini ta krainakh YeS: porivnialnyi analiz [Constitutional legal framework for financing political parties in Ukraine and EU countries: comparative analysis]. Candidate's thesis. Uzhhorod: Uzhhorodskyi natsionalnyi universytet [in Ukrainian].

27. Yanh L. (2002). Rehuliatsiia politychnoho finansuvannia u liberalno-demokratychnykh suspilstvakh [Regulation of Political Financing in Liberal-Democratic Societies]. Kyiv [in Ukrainian].

28. Williams R. (2000). Aspects of Party Finance and Political Corruption. Party Finance and Political Corruption. (p. 1-13). London: Macmillan [in English].

29. Williams R. (2000). Aspects of Party Finance and Political Corruption. Party Finance and Political Corruption. (p. 1-13). London: Macmillan [in English].

30. Yanishevskyi S. O. (n.d.). Derzhavne finansuvannia statutnoi diialnosti politychnykh partii: dosvid YeS i napriamy udoskonalennia vitchyznianoho zakonodavstva [State financing of statutory activities of political parties: EU experience and directions of improvement of domestic legislation]. www.niss.gov.ua. Retrieved from http://www.niss.gov.ua/articles/2900 [in Ukrainian].

31. Guidelines and Report on the Financing of Political Parties adopted by the Venice Commission at its $46^{\text {th }}$ Plenary Meeting (Venice, 9-10 March 2001). CDL-INF(2001)008-e. (n.d.). www.venice.coe.int. Retrieved from https://www.venice.coe.int/ webforms/documents/?pdf=CDLINF(2001)008-e [in English].
32. Rekomendatsiia N Rec (2003) 4 Komitetu ministriv Rady Yevropy derzhavam-chlenam "Pro zahalni pravyla borotby z koruptsiieiu pry finansuvanni politychnykh partii i vyborchykh kampanii" [Recommendation N Rec (2003) of the 4 Committee of Ministers of the Council of Europe to member states on "General rules for combating corruption in the financing of political parties and electoral campaigns"]. (n.d.). zakon.rada.gov.ua. Retrieved from https://zakon.rada.gov. ua/laws/show/994_867 [in Ukrainian].

33. Rekomendatsiia PARIe "Finansuvannia politychnykh partii" vid 22.05.2001, № 1516 (2001) [PACE Recommendation "Financing of $\mathrm{Po}$ litical Parties” dated May 22 2001, № 1516 (2001)]. (n.d.). crimecor.rada. gov.ua. Retrieved from http://crimecor.rada.gov.ua/komzloch/control/ uk/publish/article;jsessionid=DCB1 8A3AA744DB458FFEC474D147FA 17 ?art_id $=48962 \&$ cat_id $=46352$ [in Ukrainian].

34. Rekomendatsiia N Rec (2003) 4 Komitetu ministriv Rady Yevropy derzhavam-chlenam "Pro zahalni pravyla borotby z koruptsiieiu pry finansuvanni politychnykh partii i vyborchykh kampanii" [Recommendation N Rec (2003) of the 4 Committee of Ministers of the Council of Europe to member states on "General rules for combating corruption in the financing of political parties and electoral campaigns"]. (n.d.). zakon.rada.gov.ua. Retrieved from https://zakon.rada.gov. ua/laws/show/994_867 [in Ukrainian].

35. Dzhuhan V. V. (2017). Konstytutsiinopravovi zasady finansuvannia politychnykh partii v Ukraini ta krainakh YeS: porivnialnyi analiz [Constitutional legal framework for financing political parties in Ukraine and EU 
countries: comparative analysis]. Candidate's thesis. Uzhhorod: Uzhhorodskyi natsionalnyi universytet [in Ukrainian].

36. Strom K. A. (1990). Behavioral theory of competitive political parties. American journal of political science, 34 (2), 565-598 [in English].

37. Schlesinger J. A. (1984). On the Theory of Party Organization. The Journal of Politics, 46 (2), 369-400 [in English].

38. Naßmacher, K.-H. (2009). The Funding of Party Competition: Political finance in 25 democracies. BadenBaden: Nomos [in English].

39. Recommendation 1516 (2001) "Financing of political parties" : adopted by Parliamentary Assembly of the Council of Europe on 22 May 2001. (n.d.). www.assembly.coe.int. Retrieved from http://www.assembly.coe. int/nw/xml/XRef/Xref-XML2HTML-en.asp?fileid=16907\&lang=en [in English].

40. van Biezen, I. (n.d.). Campaign and party finance. www.hks.harvard.edu. Retrieved from https://www.hks.harvard.edu/fs/pnorris/Acrobat/Chapter\%205\%20Van\%20Biezen\%20Campaign $\% 20$ and $\% 20$ party $\% 20$ finance. pdf [in English].

41. Monitorynh'2018: osnovni tendentsii zmin hromadskoi dumky [Monitoring'2018: the main tendencies of changes in public opinion]. (2018). dif. org.ua. Retrieved from https://dif.org. ua/article/monitoring2018-osnovnitendentsii-zmin-gromadskoi-dumki [in Ukrainian].

42. Tsatsos D., Bleckmann A., Bothe M. (1965). Die Finanzierung politischer Parteien: ein rechtsvergleichender Uberblick. Zeitschrift für ausländisches öffentliches Recht und Völkerrecht, 25, 524-550 [in German].

43. Kopecký P. (2006). Political parties and the state in post-communist Europe: The nature of symbiosis. Journal of Communist Studies and Transition Politics, 22, 251-273 [in English].

44. Zakon Ukrainy "Konstytutsiia Ukrainy" : vid 28.06.1996 r. [The Law of Ukraine "The Constitution of Ukraine" from 28.06.1996].(n.d.).zakon.rada. gov.ua. Retrieved from http:// z a k on 2.rada.gov.ua/law s / s how / $254 \%$ D $0 \%$ B A / 96 $\%$ D0\%B2\%D1\%80 [in Ukrainian].

45. Zakon Ukrainy "Pro politychni partii v Ukraini” : vid 01.10.2018, № 2365III [Law of Ukraine "On Political Parties in Ukraine” from 01.10.2018, № 2365-III]. (n.d.). zakon.rada.gov. ua. Retrieved from https://zakon. rada.gov.ua/laws/show/2365-14 [in Ukrainian].

46. Zakon Ukrainy "Pro vybory narodnykh deputativ Ukrainy" : vid 25.03.2004 r.[Law of Ukraine "On the election of people's deputies of Ukraine" from 25.03.2004]. (n.d.). zakon.rada.gov.ua. Retrieved from http://zakon5.rada.gov.ua/laws / show/1665-15/ed20060318/page [in Ukrainian].

\section{СПИСОК ВИКОРИСТАНИХ ДЖЕРЕЛ}

1. Про політичні партії в Україні: Закон України від 2001 р. № 2365-III // Відомості Верховної Ради України. - 2001. - № 23. - Ст. 118. URL: https://zakon.rada.gov.ua/laws / show/2365-14 (Дата звернення: 05.01.2019).

2. Про внесення змін до деяких законодавчих актів України щодо запобігання і протидії політичній корупції: Закон України від 2015 р. № 731-VIII // Відомості Верховної Ради України. - 2015. - № 49-50. Cт. 449. URL: https://zakon.rada. gov.ua/laws/show/731-19\#n60 (дата звернення: 05.01.2019). 
3. Bartolini St. Identity, competition, and electoral availability. The stabilization of European electorates 1885-1985. Cambridge: Cambridge University Press, 1990. - 383 p.

4. Dalton R.J. Political parties and political representation. Party supporters and party elites in nine nations. Comparative political studies. London, Thousand Oaks, New Dehli, 1985. Vol. 18. N. 3.

5. Budge I., Keman H. Parties and democracy. Coalition formation and government functioning in twenty states. Oxford, 1990.

6. Budge I., Keman H. Parties and democracy. Coalition formation and government functioning in twenty states. Oxford, 1990.

7. Laver M., Hunt W. B. Policy and party competition. New York, 1992.

8. Laver M., Schofield N. Multiparty government. The politics of coalition in Europe. Oxford, New York, 1990.

9. Laver M., Hunt W. B. Policy and party competition. New York, 1992.

10. Janda K., Harmel R, Edens C., Goff P. Changes in party identity: evidence from party manifestos // Party politics. London, Thousand Oaks, New Dehli, 1995. Vol. 1. № 2.

11. Dalton R.J. Political parties and political representation. Party supporters and party elites in nine nations. Comparative political studies. London, Thousand Oaks, New Dehli, 1985. Vol. 18. № 3.

12. Dalton R. J. Citizen politics: public opinion and political parties in advanced western democracies. Chatham, 1996.

13. Dalton R. J., Flanagan S. C, Beck P. A. (eds.). Electoral change in advanced industrial democracies: realignment or dealignment? Princeton, 1984.

14. Dalton R. J., Flanagan S. C, Beck P. A. (eds.). Electoral change in advanced industrial democracies: realignment or dealignment? Princeton, 1984.

15. Niedermayer $O$. Zur systematischen analyse der entwicklung von parteiensystemen // wahlen und politische einstellungen in westlichen demokratien / O. W. Gabriel, J. W. Falter, (hrsg.). Frankfurt am Main U. A., 1996.

16. Ware A. Political parties and party systems. Oxford, New York, 1996.

17. Helms $l$. Parteien und fraktionen. Ein internationaler vergleich. Opladen, 1999.

18. Гонюкова Л. Політичні партії як інститут державної політики та управління: теоретико-методологічний аналіз: монографія. - Київ, 2009. $392 \mathrm{c}$.

19. Коцюруба О. Публічне фінансування політичних партій: перспектива для України на досвіді Польщі // Вісн. Львівського ун-ту. Серія юридична. - 2013. - № 57. - С. 179-188.

20. Обушний С. М. Фінансове забезпечення діяльності політичних партій в Україні: дис. ... канд. екон. наук : 08.00.08. - Київ, 2007. - 186 с.

21. Примуш М. В. Політико-правове регулювання діяльності політичних партій: монографія. - Донецьк, 2001. - $338 \mathrm{c}$.

22. Мартинюк $P$. Партійна система України та регіональні чинники в iii розвитку. Політологічні та соціологічні студії // Зб. наук. пр. П50 T.IX. - Чернівці, 2010. - С. 180-192.

23. Романюк А. С., Шведа Ю. Р., Шумельда О. В. Політико-правові аспекти фінансування політичних партій: світовий досвід та Україна. - Львів, 2003. - 132 c.

24. Романюк А. С., Шведа Ю. Р., Шумельда О. В. Політико-правові аспекти фінансування політичних партій: світовий досвід та Україна. - Львів, 2003. - 132 c.

25. Романюк А. С., Шведа Ю. Р., Шумельда О. В. Політико-правові аспекти 
фінансування політичних партій: світовий досвід та Україна. - Львів, 2003. - 132 c.

26. Джуган B. B. Конституційно-правові засади фінансування політичних партій в Україні та країнах СС: порівняльний аналіз: дис. ... канд. юрид. наук (доктора філософіі) за спец. 12.00.06 "Конституційне право; муніципальне право”. Ужгород. нац. ун-т. - Ужгород, 2017. - С. 82.

27. Янг Л. Регуляція політичного фінансування у ліберально-демократичних суспільствах: монографія. Київ, 2002. - 96 с.

28. Williams $R$. Aspects of Party Finance and Political Corruption. In Party Finance and Political Corruption. 2000. - London: Macmillan. - 214 p.

29. Williams R. Aspects of Party Finance and Political Corruption. In Party Finance and Political Corruption. 2000. - London: Macmillan. - 214 p.

30. Янішевський C. О. Державне фінансування статутної діяльності політичних партій: досвід СС і напрями удосконалення вітчизняного законодавства. Аналітична записка. Нац. ін-т стратегічних досліджень. URL: http://www.niss.gov. ua/articles/2900/ (Дата звернення: 05.01.2019).

31. Керівні принципи та доповідь щодо фінансування політичних партій (Венеціанська Комісія (0910).03.2001 (CDL-INF(2001)008)).

32. Рекомендації Парламентської Асамблеї Ради Європи від 22 травня 2001 р., № 1516. Фінансування політичних партій. URL: http://crimecor. rada.gov.ua/komzloch/control/uk/ publish/article; jsessionid = DCB18A (дата звернення: 05.01.2019).

33. Рекомендація ПАРЕ "Фінансування політичних партій” від 22.05.2001 р. № 1516(2001).

34. Рекомендація Комітету Міністрів Ради Свропи “Про загальні правила боротьби з корупцією при фінансуванні політичних партій та виборчих кампаній” від 08.04.2003 p. Rec 2003 (4).

35. Джуган B. В. Конституційно-правові засади фінансування політичних партій в Україні та країнах ЄC: порівняльний аналіз: дис. ... канд. юрид. наук (доктора філософіі) за спец. 12.00.06 “Конституційне право; муніципальне право”. Ужгород. нац. ун-т. - Ужгород, 2017. C. 82.

36. Strom K. A. Behavioral theory of competitive political parties // American journal of political science. Oxford, 1990. Vol. 34. - № 2.

37. Schlesinger Joseph A. On the Theory of Party Organization // The Journal of Politics 1984 46:2, 369-400 p.

38. Naßmacher Karl-Heinz. The Funding of Party Competition Baden-Baden (Nomos Verlag), 2009.

39. Financing of political parties : Recommendation 1516 (2001) : [adopted by Parliamentary Assembly of the Council of Europe on 22 May 2001]. URL: http://www.assembly.coe.int/ nw/xml/XRef/Xref-XML2HTMLen.asp?fileid=16907\&lang=en （дата звернення: 06.01.2019).

40. Biezen I. van. Campaign and party finance. URL:https://www.hks.harvard.edu/fs/pnorris/Acrobat/Chapter\%205\%20Van\%20Biezen\%20Campaign \%20and\%20party\%20finance. pdf (дата звернення: 05.01.2019).

41. "Моніторинг-2018: основні тенденції змін громадської думки”. Соціологічне опитування Інституту соціології НАН України та Фонду “Демократичні ініціативи” імені Ілька Кучеріва в рамках Програми сприяння громадській активності “Долучайся!”. URL: https://dif.org. ua/article/monitoring2018-osnovnitendentsii-zmin-gromadskoi-dumki (дата звернення: 06.01.2018). 
42. Tsatsos D., Bleckmann A., Bothe M. Die Finanzierung politischer Parteien: ein rechtsvergleichender Uberblick. Zeitschrift für ausländisches öffentliches Recht und Völkerrecht. - 1965. № 25. - P. 524-550.

43. Kopecký P. Political parties and the state in post-communist Europe: The nature of symbiosis // Journal of Communist Studies and Transition Politics. - 2006. - № 22. - P. 251273, 262.

44. Конституція України: Закон України від 28 червня 1996 р. URL: http:// zakon2.rada.gov.ua/laws/show/254\%
D0\%BA/96-\%D0\%B2\%D1\%80 (дата звернення: 05.01.2019).

45. Про політичні партії в Україні: Закон України від 2001 р. № 2365-III // Відомості Верховної Ради України. - 2001. - № 23. Ст. 118. URL: https://zakon.rada.gov. ua/laws/show/2365-14 (Дата 3вернення: 05.01.2019).

46. Про вибори народних депутатів України : Закон України від 25 березня 2004 p. URL: http://zakon5. rada.gov.ua/laws/show/1665-15/ ed20060318/page (дата звернення: 05.01.2019) 